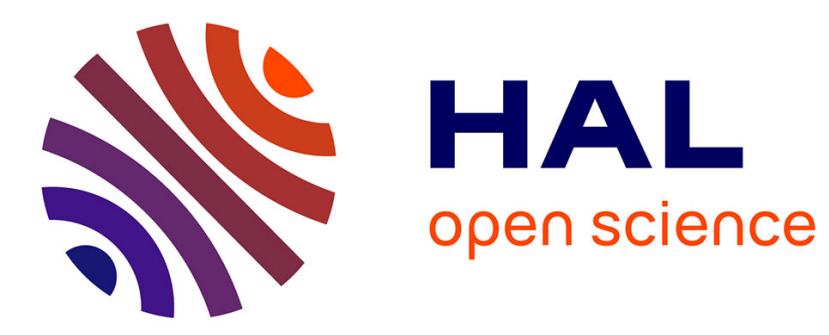

\title{
Italophilia meets Albanophobia: paradoxes of asymmetric assimilation and identity processes amongst Albanian immigrants in Italy
}

Russell King, Nicola Mai

\section{- To cite this version:}

Russell King, Nicola Mai. Italophilia meets Albanophobia: paradoxes of asymmetric assimilation and identity processes amongst Albanian immigrants in Italy. Ethnic and Racial Studies, 2008, 32 (1), pp.117-138. 10.1080/01419870802245034 . hal-00513309

\section{HAL Id: hal-00513309 \\ https://hal.science/hal-00513309}

Submitted on 1 Sep 2010

HAL is a multi-disciplinary open access archive for the deposit and dissemination of scientific research documents, whether they are published or not. The documents may come from teaching and research institutions in France or abroad, or from public or private research centers.
L'archive ouverte pluridisciplinaire HAL, est destinée au dépôt et à la diffusion de documents scientifiques de niveau recherche, publiés ou non, émanant des établissements d'enseignement et de recherche français ou étrangers, des laboratoires publics ou privés. 


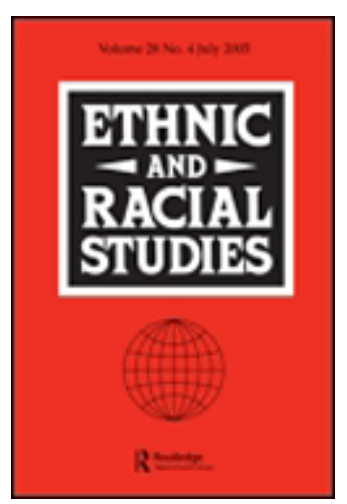

Italophilia meets Albanophobia: paradoxes of asymmetric assimilation and identity processes amongst Albanian immigrants in Italy

\begin{tabular}{|r|l|}
\hline Journal: & Ethnic and Racial Studies \\
\hline Manuscript ID: & RERS-2007-0129.R2 \\
\hline Manuscript Type: & Original Manuscript \\
\hline Keywords: & $\begin{array}{l}\text { Albanian migration, Italy, assimilation, integration, Identity, } \\
\text { stigmatisation }\end{array}$ \\
\hline
\end{tabular}

\section{s ScholaronE \\ Manuscript Central}




\title{
Italophilia meets Albanophobia: paradoxes of asymmetric assimilation and identity processes amongst Albanian immigrants in Italy
}

\author{
Russell King and Nicola Mai
}

\begin{abstract}
This paper discusses what we call the 'Albanian assimilation paradox'. Since arrival in 1991, Albanians have become one of the most 'integrated' of all non-EU immigrant groups in Italy, based on their knowledge of Italian, geographical dispersion, balanced demography, employment progress, and desire to remain in Italy. Yet they are the nationality most rejected and stigmatised by Italians - stereotyped as criminals, prostitutes and uncivilised people. Based on 97 interviews with Albanians in three cities in Italy, we explore the multifaceted dimensions of their patchy assimilation. Although the hegemonic negative framing of Albanians by Italian media and public discourse plays a major role, other elements of the picture relate to Albanians' complexly shifting identities, framed both against and within this discourse (and hence both resisting and internalising it), and against changing concepts of Albanian national and diasporic identities derived from ambiguous perceptions of the national homeland.
\end{abstract}

Keywords: Albanian migration; Italy; assimilation; integration; stigmatisation; identity 


\section{Introduction and theoretical reference-points}

Two refrains echo through the hundreds of conversations we have had with Albanian immigrants living in Italy. The first is an overwhelming sadness at the stigmatisation they have been subjected to by the Italian media and society. Their reactions to stereotyping as 'undesirables' and 'criminals' range from extreme anger to resignation and even to tacit acceptance and internalisation. The second refrain is often framed as a question: 'Why won't they let us be like them?' This can be seen as an inversion of the title of Greeley's (1969) famous essay about immigrants in the United States 'Why can't they be like us?' By deploying the term 'asymmetric assimilation' we explore in this paper the inclusion/exclusion of Albanian migrants in Italy. Our neologism is not without historical precedent or analogy, as we shall see shortly. We propose its application to the Albanian case because of the paradoxical situation whereby the migrant group which is the most rejected by Italian society is that which, on several indicators, is also the most 'similar' to the host society, and moreover sees itself as such.

For a long time now, assimilation and integration have been dominant themes in the study of immigration. Although there are important earlier origins in Europe in Durkheimian sociology and in the Chicago School in the US, we pick up the theoretical debate with Milton Gordon's canonical Assimilation in American Life. Gordon (1964) made a key division into structural assimilation (engagement in multiple primary-group relations with the host society, entering into social institutions and structures), and identificational assimilation (taking on a sense of host-society 'peoplehood'); Gordon correlates the latter, although not exactly, to cultural assimilation or acculturation. This division has passed across into the European literature on integration, which is much more recent (see e.g.Vermeulen and Penninx 2000). Hence European authors commonly make distinctions between structural, socio-cultural and identificational integration; or between formal participation in sectors such as education or the employment market, and informal participation in neighbourhood relations and leisure activities (Engbersen 2003; Heckmann 2005).

Returning to Gordon, we note one of his major propositions: 'Once structural assimilation has occurred, either simultaneously with or subsequent to acculturation, all the other types of assimilation [here Gordon is referring to intermarriage, erosion of discrimination, absence of power differentials etc.] will naturally follow' (Gordon 
1964, p. 81, italics in original). According to Gordon, structural assimilation inevitably produces acculturation, but not the reverse; indeed, for the US, Gordon's thesis is that 'whilst acculturation has been substantially achieved, this is not the case with regard to the other assimilation variables' (1964, p. 105). ${ }^{1}$ Gordon's concept of 'acculturation without assimilation' will be used as a template against which to assess the Albanian experience in Italy. We will see that it approximates, but is not identical to, our preferred notion of asymmetric assimilation.

We suggest, by way of signposts into our analysis, three essential differences between Gordon's model and our findings. The first is Gordon's curious omission of substantive discussion of the labour market, a key component of subsequent assimilation/integration literature, especially in Europe. Second, Gordon suggests (1964, p. 81) that acculturation implies the disappearance of prejudice and discrimination, which is definitely not the situation in our case-study. Third, Gordon's account carries little acknowledgement of how different immigrant groups' aspirations for assimilation might be matched (or not) by the host society's hegemonic perceptions of the 'assimilability' of different groups.

Gordon's landmark analysis was of course only a stage in the evolution of the assimilation debate. Subsequently assimilation become a discredited term (Glazer 1993), although some revival can recently be noted, both in the United States (Alba and Nee 1997) and in Europe (Brubaker 2001). Key to the concept's rehabilitation has been a shift away from the original assumption of 'straight-line assimilation' into 'Anglo-conformity' (in the US context) to a more nuanced and analytically complex use of the term. Much attention has been given to alternative models of assimilation, notably the segmented assimilation of Portes and Zhou (1993), but this line of analysis focuses on the second generation, less relevant to Albania where the migration is less than a generation old. Finally, much depends on national models of immigrant integration and exclusion; within Europe France has been the country where the assimilationist tradition has been most strongly represented (Brubaker 2001, pp. 535-7).

In the case of Italy, a recent country of immigration, there is as yet no overarching model of immigrant incorporation. Policy measures have been ad hoc and frequently contradictory. There seems to be an acceptance of the economic rationale of harnessing migrant labour and of the inevitability of immigration in a scenario of enhanced global mobility; and yet the trend in legislation - from the Legge Martelli 
(1990) through the Turco-Napolitano (1998) to the Bossi-Fini law (2002) - has been to pay lip-service to integration and instead to keep immigrants as a marginalised, temporarily-resident fraction of Italian society (Zincone 2006). Italian press and other media have reinforced this stance by continuously representing immigrants as outsiders and a threat to the nation. Throughout the 1990s and since, Albanians have been the lightning-rod for this negative discursive framing of immigration.

In this paper we look at the assimilation-integration trajectory not from the side of national models or policy but from the perspective of an individual migrant group Albanians. Our evidence base is 97 in-depth interviews, taped and transcribed, with Albanian immigrants in three Italian cities - Rome, Modena and Lecce. These cities were strategically chosen to represent different socio-economic conditions for migrants in Italy (respectively the capital and medium-sized cities in the industrialised North and less-developed South). Interviewees were carefully selected to cover a cross-section of migrant backgrounds and experiences. Whilst the interview survey is quite large for a qualitative study, we acknowledge that the statistically nonrepresentative nature of the sample limits the generalisability of some of our findings.

We now set the scene by briefly describing the chronology and character of the Albanian migration to Italy.

\section{The Albanian arrival in Italy}

Albania represented the most 'extreme' of the Eastern bloc's state socialist regimes: closed-off and paranoid about the 'outside world', ruled by Enver Hoxha, 'dictator of the people', for 40 years. Just as one extreme begets another, Albania's postcommunist transformation, in the country which was the last domino to fall, was the most abrupt and turbulent. The sudden lurch from stalinist gulag to capitalist chaos saw proportionally the biggest emigration from any former Eastern bloc country: by 2005 a quarter of the population was living abroad (Government of Albania 2005).

The first mass departures took place in March 1991: across the Adriatic Sea to Italy and over the mountains to Greece (King 2003). The 26,000 boat-migrants who arrived within a few days on the South Italian shore were accepted as refugees, put in reception camps and eventually dispersed to different parts of Italy. A special provision of the Martelli Law was passed in order to grant them work and residence rights. A very different reaction greeted the arrival of another wave of Albanian boat- 
people in August 1991: by this time Albania had a democratically-elected government and so it was argued that the new arrivals could no longer be treated as refugees fleeing a repressive regime. Most of them were sent back to Albania. A similar scenario was replayed in 1997 when a further boat exodus was triggered by the collapse of several pyramid savings schemes, a financial disaster which bankrupted maybe half of Albanian households. Once again, the first migrants were accepted, but then attitudes quickly hardened and later arrivals were blocked or returned.

The arrival of those boats, packed to the gunwales, with migrants perched on every available surface, and shinning down the ropes to the quayside, has become part of the iconography of migration, not only in Italy but worldwide. The boat is highly symbolic of the 'migrating crowd', since it gathers together the greatest mass of migrants in a single confined space, berthing on the shore of 'fortress Europe'. The images filled the Italian TV screens and the pages of the print media, not to mention a controversial Benetton poster and Gianni Amelio's celebrated film Lamerica (1994).

Such imagery gives a distorted view of Albanian migration. Whilst it is true that most Albanians have migrated clandestinely - it could not be otherwise given the refusal of West European governments to accept them as legal migrants - their journeys have been less visually spectacular. Most came either in high-powered dinghies across the Strait of Otranto, or via more circuitous routes through Greece and (ex-)Yugoslavia. Others arrived on ferries or planes, travelling with visitor visas or false documents, and then 'overstayed'. Continuous now for 17 years, emigration seems set to persist; high birth-rates in the recent past ensure a supply of aspiring emigrants for the next decade or so.

Data on permits to stay (permessi di soggiorno) are the most complete source for documenting the evolving profile of the Albanian presence in Italy. Table 1 shows how Albanians quickly became one of the largest immigrant nationalities in Italy over the short time since 1991. At the end of 2005 they numbered 255,704 and vied with Romanians $(270,850)$ and Moroccans $(235,000)$ for the 'top' position. Albanians were also prominent in Italy's three recent regularisations - in 1995 (29,744 Albanians regularised), $1998(39,454)$ and $2002(55,038)$ - transforming the community from a largely undocumented status to a predominantly 'legal' one.

[Table 1 near here] 
In trying to understand the significance of Albanian migration to Italy, and the new ascribed identities that were created (both for Albanians and Italians), the timing of this intensely mediatised migratory inflow was vital. It came precisely when Italy itself was in deep crisis. The end of Cold-War communism blew away the anticommunist cleavage around which the Italian political system had been structured throughout the postwar era: 45 years of communist rule in Albania had been paralleled by 45 years of Christian Democracy in Italy, and both collapsed within months of each other. Moreover, the demise of the Christian Democrats' inefficient and morally bankrupt political system was coupled with new and stringent demands posed by European integration. Italy's membership of the EU was put to the test in its questionable ability to comply both with the Maastricht economic parameters and with the Schengen Treaty (Perlmutter 1998). These events unfolded alongside the Albanian crisis, which gave Italy an opportunity to exercise 'responsible' foreign policy (leading the military-humanitarian missions in Albania in the early 1990s and again in 1997) and to regain 'Schengen credibility' by acting tough on immigration, especially along its southern Adriatic border. Thus, a new Italian national identity 'efficient', 'European', 'global' - emerged in relation to the new constitutive others appearing on the scene at the time - Albania and the Albanians (Mai 2003).

Meanwhile, on the other side of the Adriatic Sea, 'emigration fever' characterised Albania during the 1990s. Leaving the country was seen as the only route to economic survival and improvement and - especially for younger people - to expressing their own identity. Ever since 1991, if not well before, much of this 'disidentification' with Albania has been projected towards Italy, Albania's nearest Western neighbour. ${ }^{2}$ Mussolini's colonial ventures in Albania may have something to do with this - remodelling Tirana and reclaiming the coastal marshlands - but much more powerful in the 'italianisation' of Albania was the beaming of TV channels towards Albania from the 1970s on. The illegal, hence, secret watching of Italian television gave Albanians a periscope with which to observe the outside world. Especially for young people, Italian TV projected lifestyle models which were very different from those assigned to them by communism. In this way the idea of migrating abroad (above all to Italy) could be seen as the logical outcome of a wider process of disembedding of Albanian young people's identities from the homogenous, moralised, collectivist-nationalist landscape that prevailed before 1991 (Mai 2002, p. 262). Hoxha's xenophobia was replaced by a people's xenophilia targeted particularly 
at Italy as the symbol of Albanians' aspirational Westernness. What we are arguing here, in essence, is that Albanians, especially teenagers and young adults, had already undergone a process of anticipatory assimilation to Italy and its way of life even before their 'migratory projects' became realisable. Moreover, years of watching Italian television had given most young Albanians a reasonable command of the Italian language - an invaluable headstart should they end up migrating there.

\section{From 'guardian angels' to 'albanophobia'}

The Italian response to the arrival of tens of thousands of Albanians has been a story in itself. The reaction has been strongly driven by the Italian media, which have a tradition of stereotyping immigrants: before the arrival of Albanians, Moroccans and Tunisians were routinely associated with crimes such as drug-dealing and theft (Campani 2001; ter Wal 2002). But, more than any other group in recent years, Albanians have been subject to a brutal campaign of stigmatisation and criminalisation by the Italian media (King and Mai 2002).

At the very beginning, reaction to the Albanians' landing was sympathetic. In March 1991 the boat-migrants were welcomed as 'Adriatic brothers' escaping the 'darkness of communism' (Zinn 1996). During our fieldwork in and around the arrival-points of the migrants in Apulia, we collected accounts of extraordinary hospitality by local people towards the new arrivals - not only donations of food, clothing and furniture, but cases of long-term support and 'adoption' of Albanians by local families who became effectively their 'guardian angels' (King and Mai 2004).

Even at this early stage, however, there were also more ambiguous and ultimately disturbing framings of the arrival. News articles portrayed the Albanians as desperate, poverty-stricken, abject, child-like. Pictures of them massed on the quaysides or cooped up in reception centres gave the impression that they were incapable of helping themselves - whereas in fact they were the victims of the authorities' dithering. By the time the August 1991 wave arrived, the tone had further changed. A media discourse which in March had stressed words like 'exodus', 'refugees', 'emergency' and 'help' had changed to keywords such as 'crisis', 'clandestine arrivals', 'illegal immigrants' and 'repatriation' (Palomba and Righi 1992).

This was but a step on the way to Albanians' final and comprehensive denigration as 'undesirables' and 'criminals', persistently associated in the media with human 
trafficking, drugs, prostitution, burglaries and violent behaviour. As in Greece (cf. Lazaridis 1996), albanophobia, an all-encompassing and irrational fear of all things Albanian, became entrenched within the perceptions of the Italian population as a whole. As Vehbiu and Devole (1996) lament in their devastating critique of Italian media's 'discovery' and then 'destruction' of the Albanians, almost never do the media report on the real and law-abiding progress made by the vast majority. Instead, criminalisation became a powerful agent in stereotyping all Albanian migrants.

Interviewees were acutely aware of the media's framing of Albanians and of the heavy burden this imposed on all Albanians in their interactions with the host society - and even with each other. A typical interview extract:

\footnotetext{
Well, I think that the Italian media have orchestrated a propaganda campaign against Albanians. They only show the worst of Albania.

Do you think Italians are influenced by this?

Very negatively. I mean the truth is that not all Albanians are criminals ... Even Albanians are afraid of other Albanians ... (Male, age 28, Lecce).
}

The next interview exchange, with a translator/interpreter at the Lecce law court, is interesting because it reflects the view of an educated person who is confronted daily by criminal cases involving Albanians.

\footnotetext{
How do you think Albanian migrants are treated here?

Very badly ... the mass media have given us a very bad press.

Is this an important factor? Does it influence the way Italians behave towards Albanians?

Yes, very important. Because if something bad happens, the first thing everybody says is that Albanians did it. And of course they don't bother to rectify the information when it turns out that it's not true ...

Since you have direct knowledge of Albanians' involvement in criminality, what do you think of the relationship between the extent of the phenomenon and how it's portrayed?
} 
It's true, I see Albanians getting involved in drugs, refugee smuggling and prostitution ... But it's only a small minority of people, who destroy the work and sacrifice of honest people who are the overwhelming majority (F, 31, Lecce).

The relentless stereotyping of Albanians as criminals and more generally as rough, uncivilised people has two further important ramifications. The first is the behaviour of Italians towards Albanians in various spheres of life such as employment and housing. Although Albanians have little difficulty obtaining low-status jobs in Italy, we came across many instances of discrimination in the workplace, including receiving lower wages than Italians doing the same work. This becomes less common as time passes and Albanians get legalised and progress to more stable jobs - this holds for all immigrants who start as undocumented workers in the informal labour market. More specifically anti-Albanian discrimination arises when Albanians try to access qualified jobs: there appears to be a glass ceiling. One informant ( F, 30, Modena) related how she had been interviewed for a post as a clerical officer; all had gone well until the final question. The job contract was on the table and about to be signed when the nationality question arose. When she said she was Albanian the contract was withdrawn and 'another candidate' was suddenly introduced into the conversation. They would phone her when the other candidate had been interviewed. She never received the call.

Instances of more subtle racism towards Albanians derive from their conversational encounters with Italian colleagues or acquaintances. One example among many:

When you say you're Albanian what do people say?

Ah ... very good ... you don't look like one!

And how do you respond to that?

Well, usually I say that we don't have three eyes or four ears, and start laughing! (F, 22, Lecce).

The second ramification involves Albanians' internalisation of the stigmatising discourse, so that it affects their own self-presentation and their behaviour towards both Italians and other Albanians. Several interviewees seemed to accept that 
Albanians had behaved badly and that the poor reputation of their national group was partially deserved. One reaction was to socialise mainly with Italians and to avoid fellow-Albanians who were not part of their kinship or close friendship group.

Those Albanians who commit crimes and have problems with the law, I think they deserve the treatment they get from society, but the rest, people like us who are law-abiding and yet are in need of help, don't deserve the racism (...) I feel a bit diffident towards Albanians now ... I socialise mainly with Italians. The only Albanians I mix with are my family (F, 31, Lecce).

The next interview exchange illustrates an even more explicit rejection of the Albanians' - prefixed by the definite article as if they were a different nationality from the interviewee:

\title{
Are your friends Italian or Albanian?
}

I don't know many Albanians. I stay with my family. I don't like to make acquaintances with the Albanians, I don't like them ... they have done many stupid things (M, 24, Modena).

Another reaction is to deny being Albanian:

\begin{abstract}
Once this lady, a shopkeeper, asked me if I was from Sardinia since she thought my accent was like the Sardinian one ... I replied yes. I felt bad about that, but it was a kind of natural reaction ... (M, 39, Lecce).
\end{abstract}

Finally, parents want to ensure that their children are not identified as Albanian and picked on as a result, so they encourage them to speak Italian all the time at school and in public spaces such as the street (Zinn 2005). Teenagers we interviewed who had spent time in school in Italy recalled being isolated, taunted, accused of having diseases. The leader of an Albanian association in Lecce said: 


\section{Albanians' aspirational assimilation: some qualitative and quantitative data}

We saw earlier how Albanians, even before they left their country, had been subject to a yearning to move abroad; and we noted a kind of 'anticipatory socialisation' into Italian culture. Now we build on these findings about Albanians' identificatory orientation towards Italy by presenting a range of data to illustrate, more systematically, Albanians' partially-successful assimilation into Italian society. What is also remarkable is that this fast movement along the assimilation-integration trajectory has been achieved in a short space of time compared to longer-established immigrants in Italy.

We start with the labour market. There are no employment data to demonstrate statistically the progress made by Albanians since their arrival in Italy. But most interviewees, especially those who had been in Italy for many years, described their work experiences in terms which involved moves towards better jobs, pay and conditions. Often a major factor in this was the acquisition of 'papers'. Here are three testimonies which are typical of many we recorded. We select these because they represent different types and ages of informants and different scenarios of work improvement.

I went through some very difficult times at the beginning ... I tried hard to get a job and all I could find was a manual job in a factory, where I worked for almost four years. After that, I managed to become a translator. I had always wanted to do this as it was my sort of 'natural' role since I first arrived in Italy, as I was usually the one who spoke Italian well wherever I went ... 
So, what happened in the difficult period? How did you find these jobs?

I asked everywhere, through ads, friends, even the internet. Whenever they found out I was Albanian they said they would think about it and that was it ... nobody ever called me. Except for the job at the factory, but I got that through an Italian friend. At the same time, they kept contacting me to work as a translator at the court and little by little I became one of their main consultants. I attended a course for cultural mediators organised by the province and now I freelance, offering cultural mediation, translation and interpreting services - (laughing) do you want my card? (F, 27, Modena).

I came to Italy in 1991, with the first group of migrants, and got a permit to stay as a refugee straightaway. My idea had always been to become self-employed, as that was forbidden in Albania. I thought it would be easy here ... but before I could become an entrepreneur I worked all over the place ... as a gardener, in construction, as a translator ... I came here full of hope, I had a university degree in Albania, but I had to follow a different path to get a job in Italy. Anyway it sort of worked out in the end. Now I own a bar near Stazione Termini and employ a couple of young men, an Albanian and a Romanian (M, 41, Rome).

Why did you go to evening classes?

Because I used to work during the day, first in a bakery ... then as a builder, mechanic, electrician, shop assistant ... I also did bits and pieces through temping agencies ... then I started working in a training centre, I used to teach people how to use software packages, repair computers ... And now I work as a programmer for a software company here in Modena. We develop software for big enterprises such as telecom companies and stuff like that (M, 19, Modena). 
Several issues arise from these extracts. The first is geographical location: they are from interviews in Modena and Rome. Throughout our fieldwork in the three areas in Italy, it became clear that there was a link between improving employment and a move to the North. The South was the area of arrival and acclimatisation. Here it was possible to find casual work in the shadow economy - in agriculture or construction and live without a permit to stay. But it was definitely not the best part of Italy to make economic progress: wages are lower and good jobs far fewer and more difficult to access. A move to Rome or northern Italy corresponded to a better chance, as a documented migrant, of accessing a more secure, qualified and better-paid job, or even to become self-employed; although some of this advantage would be negated by the higher cost of living, especially housing (King and Mai 2004; Schuster 2005). ${ }^{3}$

A second recurrent theme is the enormous persistence that Albanians have to show before any real progress is made. Even then many do not fulfil their true aspirations or reach the level that their skills and training (in Albania) merited, partly due to non-recognition of Albanian qualifications. We interpose one typical extract here to make this point:

\begin{abstract}
Well, to tell the truth I was disappointed with the overall experience of work here in Italy because I have a degree in accountancy and, I mean, I used to do the administration for a whole cooperative in Albania and here you will never be given such a possibility ... People say this is because there are a lot of unemployed Italians ... but I think that the fact that they do not recognise foreign diplomas is a major obstacle ... and then they don't trust you because you are Albanian, on top of it all (F, 46, Lecce).
\end{abstract}

The third feature which emerges from these interviews is language. For many immigrant nationalities arriving in Italy, language is a fundamental barrier to economic progress and social integration; much less so for Albanians who, as we have seen, often know some Italian before they arrive. Their language skills are quickly improved and many are able to 'hide' their Albanian origin. Sometimes this can lead to unforeseen consequences, as the following example illustrates. The speaker is a hospital worker who has lived both in Lecce and Modena. Her remarks are also an 
indication of the differentiated racisms towards Albanians in Italy - more 'open' and 'insulting' in the South, more subtle but perhaps deeply ingrained in the North.

Once something happened in the hospital where I am working here in Modena. A doctor overheard me talking with my mother on the phone and asked me what language I was speaking. I told him it was Albanian. He did not say anything at the time but he looked a bit confused. Then, later, he confessed to me how shocked he felt when he found out I was Albanian. He couldn't believe it - he said he would never have thought I was Albanian from the way I was working. I felt very insulted, but I knew he did not mean it in a bad way, knowing what Italian people are told about us all the time (...) Another time this cleaner insulted me, she called me an Albanian ... you know, an Albanian prostitute. This was back in Lecce. I took her to the director and made her apologise (F, 34, Modena).

We switch focus now to examine some quantitative data on Albanians in Italy. These statistics, by and large, reinforce the impression that Albanians are becoming increasingly integrated within the host society. The first index is geographical distribution. Albanians are the most 'dispersed' of all immigrant nationalities in Italy; that is to say, they are the group whose spatial distribution is most similar to that of the Italian population as a whole (Bonifazi 2007, p. 150). Albanians are found in significant numbers in all Italian regions except Sardinia and are found not only in big cities but in small towns and rural areas too.

Albanians are also highly mobile within Italy, arriving in Apulia, where of course some of them stay (in fact Albanians are 38 per cent of all immigrants in that region), but then fanning out to the rest of Italy. Regional time-series data show that Albanians tend, more than other immigrants, to move to regions of central-northern Italy which are economically dynamic and which are most accessible to their region of arrival. Hence their main regions of diffusion over the past decade stretch up the Adriatic seaboard to Emilia-Romagna and across to Tuscany (King 2003, pp. 291-3).

The evolving demographic structure of Albanians in Italy is another indicator of rapid stabilisation and integration. In the early 1990s less than a quarter were females; by the late 1990s the share was one third; by 2001 the ratio was 40 per cent. These 
gender trend-data show dynamic change towards demographic 'normalisation' (Bonifazi and Sabatino 2003, p. 970).

\section{[Table 2 near here]}

Table 2 gives further evidence of the rapid family-based settlement of Albanians in Italy, compared to the aggregate trend of all migrants from poor countries. Key figures from this table are the doubling of the share of males who are married, the very high share of Albanian females who are married (nearly three-quarters), and growth in the number of children. Data on pupil enrolments in the Italian school system (Table 3) show that over the eight years in question the number of Albanian pupils has increased more than tenfold, and the share of Albanians amongst the total foreign pupil population has more than doubled. Albanians are now the largest foreign-origin group in Italian schools, accounting for 17.7 per cent of all foreign pupils, well above their share of the overall immigrant population (11.3 per cent).

\section{[Table 3 near here]}

A final - albeit problematic - numerical indicator of assimilation is intermarriage with Italians. Mixed marriages between Italians and foreigners have increased sharply in the past decade, reaching one in ten of all marriages in 2005 (ISTAT 2007, pp. 340$3)$. Four-fifths of these marriages involved an Italian husband; only one fifth an Italian wife. How do Albanians fit into these patterns? During 2005 1,125 Albanians married an Italian spouse, accounting for 4.4 per cent of Italian-foreign unions. The 705 cases where an Albanian wife has an Italian husband are 3.8 per cent of all Italian husband out-marriages, whereas the 420 marriages between an Albanian husband and an Italian wife account for 8.6 per cent of Italian wife out-marriages. The data indicate that, although Albanians are one of the fastest-growing groups to intermarry with Italians, marriage rates remain low compared to other migrant nationalities Romanian women and Moroccan men, for instance. It seems that Albanians have yet to cross the ultimate assimilation frontier due, we suspect, to a version of the 'glass ceiling' imposed on Albanians by Italian society. Another interpretation of the relatively low out-marriage rate of Albanians is their own strong family and kinship bonds which, as noted, tend to structure their migration patterns and lead to endogamy 
rather than exogamy. Albanians' relatively balanced sex-ratio compared to many other immigrant nationalities also facilitates intra-marriage, as well as resulting from it.

\section{Discussion: shifting and opposing identities}

Whichever way one looks at Albanian migration to Italy - from the etic gaze of the social science observer, or the emic perspective of migrants' own experiences and feelings - one is confronted by a series of paradoxes and contradictions. Of course, ambivalence is intrinsic to the migrant condition, but the Albanian case seems to take these ambiguities to a new plane. Central to our attempt to capture the singularity of the Albanian migratory experience in Italy is our notion of asymmetric assimilation, the opposition of Albanians' italophilia with Italians' albanophobia. Even these two constructions are by no means univocal; within each there are a plurality of often opposing discursive frames. Our purpose now is to draw out some of these binaries and nuances.

The discussion below is based both on our formal interviews with Albanians and on our longer-term observations and interactions with this immigrant group in more informal settings. Once again, we stress that, in the absence of a statistically representative sample, some of our assertations are to be regarded as hypotheses in need of further investigation rather than iron-clad statements of fact.

First, Albanians in Italy are under-researched, yet over-represented in the media. It is not obvious why they have been so little researched. Surely it cannot be because (Italian) researchers themselves 'fear' this group. Maybe it is because Albanians are regarded as insufficiently 'visible' or 'exotic' compared to other researched groups, such as the Moroccans (Salih 2003), Senegalese (Schmidt di Friedberg 1994), Cape Verdeans (Andall 2000) or Chinese (Campani et al. 1994). The one large-scale study of Albanians in Italy (Melchionda 2003) does not take the emic perspective that we favour but relies mainly on key interviews with host-society informants.

A second set of contradictions revolves around how Albanians are viewed by Italians. As Dorothy Zinn (1996) pithily sums it up, are they 'Adriatic brethren' or 'black sheep'? This discursive dichotomy has oscillated over time, with the latter undoubtedly dominant. Recently, however, there have been signs of a softening of anti-Albanian negativity, partly because 9/11 has refocused media and political 
attention on Muslim groups in Italy such as Moroccans and Pakistanis. It is true that most Albanians are Muslim, but that is not a predominant aspect in their cultural construction and representation in Italy. Moreover, in our interviews, many Albanian Muslim migrants strategically downplayed their affiliation to Islam, which tended to be referred to in terms of family tradition rather than faith, and were prepared to baptise their children as Catholics as a way to support their children's assimilation (Romania 2004, pp. 148-53). ${ }^{4}$

This last point leads into another complex discussion about Albanians' own shifting and oppositional identities. We saw earlier how, around the period that the communist regime was crumbling in their homeland, and under the influence of Italian television-watching, Albanians were already projecting their identities towards Italy in a kind of 'anticipatory socialisation'. There is a scene in Lamerica where a truckload of Albanian young men is heading for the coast and a boat-trip to the 'promised land'. One of them speaks: 'Now I'm coming to Italy, I'll find a girl in Bari, I'll marry her and have lots of children. I won't speak Albanian to my children, I want to speak only Italian, so that the children will forget that I'm Albanian'. As a 'fantasy of radical assimilation' (Duncan 2006) this could hardly be more explicit.

Now, several years after the film and the first exodus, Albanians, including those who have yet to migrate, are much more 'migration-savvy'. They have understood (also from Albania) the Italian media's negative representation of Albanian migrants and they have been able to 'see through' the failed promises of Italian consumer capitalism (Mai 2005). Now, in what has come to be called post-post-communist times (Sampson 1998), and with the benefit of experience, Albanians are formulating different and more carefully considered life projects, focused on achieving realistic objectives.

The reappraisal of Albanian identities and ideas about migration takes on both an individual and a collective form. The contrast between these two scales of social behaviour and identification is another contradiction in the Albanian migration experience and can be interpreted, as Iosifides et al. (2007) do for Albanians in Greece, with reference to different kinds of social capital. In both Italy and Greece, and also in Switzerland (Dahinden 2005), Albanian immigrants' social capital appears to be tightly bounded by kinship, plus very close friends. For many Albanian migrants, the celebration of a 'strong' ethno-national identity seems too similar to the nationalcommunist rhetoric of their recent past. There also is a weak tendency to form 
associations, trust fellow-nationals, or even to talk to them, beyond the kin circle. Glazer and Moynihan's stripped-down definition of an ethnic group as 'something of an extended family or clan' (1970, p. 18) seems particularly apt to describe the situation of Albanians in Italy. Thus Albanians' broader-scale 'bonding' social capital, in the form of generalised ethnic solidarity, is very weak. A parallel situation is found with their 'bridging' social capital, which links them to the host society. They often develop good links with individual Italians - workmates or neighbours - but their use of institutional structures, even those set up to help them, such as job centres or charities, is again very low. Our data suggest that, in order to solve their problems of accessing work, housing or other needs, Albanians do not go to the formal or NGO structures of Italian society, nor do they utilise ethnic or immigrant associations; they resolve these issues on their own initiative through Albanian or Italian close friends and colleagues - a conclusion also supported by Melchionda (2003).

The individualisation or 'de-collectivisation' of Albanian identities is conventionally viewed as a reaction to the communist past. An interviewee:

\begin{abstract}
I think there is a refusal, a rejection of the very idea of belonging to an association ... [In communist times] associating was a way for the individual to participate in the group, but in the end it was the contrary ... the individual aspect was lost (M, 23, Modena).
\end{abstract}

We found that the Albanian associations that do exist in Italy were not established in the early years of arrival, in order to reinforce Albanians' ethnic identity and help each other settle down, but were formed in the late 1990s in order to respond to negative media images by recovering positive elements of identification. This delayed ethnic mobilisation is described in the American sociological literature as 'reactive ethnicity' and arises out of the 'confrontation with concerted attitudes of prejudice on the part of the surrounding population' (Portes and Rumbaut 1996, pp. 133, 222). In the words of an Albanian association member in Lecce:

[I became a member] because I care about the image of Albania and Albanians. I am very proud of being Albanian and I get upset when I hear people talking nonsense about us. Soon after I got here in 1997 I realised that there was a very strong prejudice against 
We have taken a lot of things from Italians. After fifty years of communism we had democracy and the model we saw was the democracy Italians had because Italy was our neighbour ... I believe we are somehow the same.... A lot of words we have and names we are giving to our children are sort of Italian. So we have their influence in different aspects of our lives (F, 35, Modena).

The fact that these similarities are not reciprocated, and in fact are replaced by narratives of stigmatisation, leads some Albanians to adopt another, more extreme assimilation strategy: mimesis (Romania 2004). This may be accompanied by an acceptance and internalisation of the rationales for stigmatisation. Others, instead, may be led to a reappraisal of their Albanian heritage, either through an embryonic and delayed growth of ethnic associations, and/or a return gaze to the homeland.

On the other hand, Italians have yet to rid themselves of the criminal-loaded stereotype they have of Albanians, and of the image they have of Albania as a basketcase - poor, chaotic and hopeless. One wonders how long it will take, and what it will take, for the stereotype to dissolve.

How can we explain the unjustifiably stark rejection of Albanians by Italian society? Much has to do with timing, as noted earlier. Albanians arrived just at the 
time when Italy was itself going through a crisis of national identification which could only be resolved by projecting elements of that crisis onto a constitutive other. But this rejective othering of Albanians is set within Italy's own internally racialised hierarchy - the fundamental opposition between the cultural construction of North Italian identity in terms of efficiency, honesty and hard work, and its South Italian symmetrical other, connoting inefficiency, corruption and laziness. As Italy fought to create a unified, 'European' national identity in the early 1990s, the Albanians intruded into the picture, replacing the semi-colonial internal other, the southerner, with a true colonial other, the outsider/insider figure of the Albanian immigrant, 'perilously close to Italians in physiological terms', and 'dangerous' precisely because this figure reminded Italians of their own disavowed southern past of poverty, emigration and brigandage (Mai 2003).

So, floating between their aspirational Italianness, their stigmatised de-italianised identities, and their uncertain relationship to a fast-changing homeland which gives them little to latch on to, Albanians take on a kind of subdiasporic identity as 'Albanians living in Italy', partially acculturated and largely unassimilated. They are part of a 'compact diaspora' or 'regional transnational space' of Albanians residing in neighbouring Italy and Greece, which nudges up against, while retaining a separate identity from, the Albanian 'inner diaspora' in Kosovo and Macedonia, as well as a 'diaspora-in-the-making' which increasingly spreads to other European countries, North America and even Australia (Mai 2005). Albanians' sense of common identity, solidarity and connectedness across these evolving diasporic zones appears to be very limited, except for family members in other countries. Of course, it takes time for diasporic identities to be consolidated, and the Albanian migration is still a relatively recent event. Right now, there is a lot of Albanian diasporic communication taking place on the internet, and nobody is researching that.

\section{Conclusion}

Let us return to some of the theoretical reference-points set out in the introduction and reflect on their relevance to our Albanian material. Gordon's notion of 'acculturation without assimilation' seems at first sight to describe the situation rather well. Albanian immigrants speak at least adequate Italian, see themselves as culturally close to Italians, and enjoy - at an individual level - good relations with neighbours and 
workmates. But not all of Gordon's acculturation criteria are met - prejudice and discrimination are rife and intermarriage is limited. For structural assimilation, too, the picture is mixed, although the lack of any published data on Albanians' employment, housing or educational performance of children in schools precludes definitive conclusions. Our evidence, supported by other qualitative survey research (Da Molin 2001; Melchionda 2003; Perrone 1998), suggests rapid progress in these spheres, although Albanians remain short of 'native' levels of achievement. Acquisition of legal status is often the key to progress in the labour market and to family formation.

The specificity of the case of Albanians in Italy resides in highly asymmetric perceptions of this group's assimilation. Of course, it is not uncommon that immigrants who foresee their own eventual assimilation are rejected by the host society; and perhaps all assimilations of immigrant-origin groups are asymmetric to some degree. An interesting historical parallel to be noted here concerns the treatment of early Italian immigrants in the United States or in Victorian London where similar discourses of roughness, dirtiness and criminality were widespread (Sponza 1988; Stella 2002). ${ }^{5}$ What makes the Albanian case unique, we believe, is the extreme polarisation of the perceptions held by the host society and the immigrant group; and the way these opposing perceptions feed off each other. The immigrants start off with high assimilation aspirations and on some of the standard indicators do achieve much. However, their rejection by Italians as the most deviant and threatening of nationalities leads them to a variety of response strategies ranging from mimesis and identity encryption to reactive ethnicity, instrumentalised as a means of challenging stereotypes. Whatever one wishes to call the particular integration status of Albanians in Italy - acculturation without assimilation, asymmetric assimilation, or other terms such as 'selective acculturation' (Portes and Rumbaut 1996, p. 252) or 'subordinate inclusion' (Melchionda 2003, p. 16) - an overriding feature is its dynamic character and therefore its capacity for rapid change over the next decade or so, when the second generation comes to maturity.

\section{Acknowledgements}

An earlier version of this paper was presented at the AHRC Diasporas, Migration and Identity Colloquium on 'Mobility and Identity: the Italian Case', University of 
Warwick, 15-16 June 2007. We also acknowledge the helpful comments of Mark Thomson, Zana Vathi and Julie Vullnetari on the draft version, as well as feedback from the three anonymous referees. Research for this article was funded by the Leverhulme Trust, grant no. F/00230/D, for which grateful acknowledgement is made.

\section{References}

ALBA, R. and NEE, V. 1997 Rethinking assimilation theory for a new era of immigration. International Migration Review, vol. 31, no. 4, pp. 826-874.

ANDALL, J. 2000 Gender, Migration and Domestic Service: The Politics of Black Women in Italy, Aldershot: Ashgate.

BONIFAZI, C. 2007 L'Immigrazione Straniera in Italia, Bologna: Il Mulino.

BONIFAZI, C. and SABATINO, D. 2003 Albanian migration to Italy: what official data and survey results can reveal. Journal of Ethnic and Migration Studies, vol. 29 , no. 6 , pp. $967-995$.

BRUBAKER, R. 2001 The return of assimilation? Changing perspectives on immigration and its sequels in France, Germany, and the United States. Ethnic and Racial Studies, vol. 24, no. 4, pp. 531-548.

CAMPANI, G. 2001 Migrants and media: the Italian case. IN KING, R. and WOOD, N. (eds) Media and Migration: Constructions of Mobility and Difference. London: Routledge, pp. 38-52.

CAMPANI, G., CARCHEDI, F. and TASSINARI, A. (eds) 1994 L'Immigrazione Silenziosa. Le Comunità Cinesi in Italia, Turin: Fondazione Giovanni Agnelli.

CARITAS/MIGRANTES 2006 Immigrazione Dossier Statistico 2006. Rome, IDOS.

COLE, J. 1997 The New Racism in Europe: A Sicilian Ethnography, Cambridge: Cambridge University Press.

DA MOLIN, G. (ed.) 2001 L'Immigrazione Albanese in Puglia, Bari: Cacucci.

DAHINDEN, J. 2005 Contesting transnationalism? Lessons from the study of Albanian migration networks from former Yugoslavia. Global Networks, vol. 5, no. 2, pp. 191-208.

DALY, F. 2001 The double passage: Tunisian migration to the south and north of Italy. IN KING, R. (ed.) The Mediterranean Passage: Migration and New Cultural Encounters in Southern Europe. Liverpool: Liverpool University Press, pp. 186-205. 
DUNCAN, D. 2006 Can the subaltern speak (without subtitles)? Speech and migrant identity in recent Italian cinema. Paper presented at the AHRC workshop on 'Mobility and Identity Formation: An Interdisciplinary Approach to the Italian Case'. University of Warwick, 9 December.

ENGBERSEN, G. 2003 Spheres of integration: towards a differentiated and reflexive ethnic minority policy. IN SACKMANN, R., PETERS, B. and FAIST, T. (eds) Identity and Integration: Migrants in Western Europe. Aldershot: Ashgate, pp. $59-76$.

GLAZER, N. 1993 Is assimilation dead? Annals of American Academy of Social and Political Sciences, vol. 530, pp. 122-136.

GLAZER, N. and MOYNIHAN, D. P. 1970 Beyond the Melting Pot, Cambridge, Mass: The MIT Press.

GORDON, M. M. 1964 Assimilation in American Life: The Role of Race, Religion and National Origins, New York: Oxford University Press.

GOVERNMENT OF ALBANIA 2005 National Strategy on Migration, Tirana: Government of Albania.

GREELEY, A. M. 1969 Why Can't They be like Us?, New York: Institute of Human Relations Press.

HECKMANN, F. 2005 Integration and Integration Policies, Bamberg: European Forum for Migration Studies.

ISTAT 2007 Rapporto Annuale 2006, Rome: ISTAT.

IOSIFIDES, T., LAVRENTIADOU, M., PETRACOU, E. and KOUTIS, A. 2007 Forms of social capital and the incorporation of Albanian immigrants in Greece. Journal of Ethnic and Migration Studies, vol. 33, no. 8, pp. 13431361.

KING, R. 2003 Across the sea and over the mountains: documenting Albanian migration. Scottish Geographical Journal, vol. 119, no. 3, pp. 283-309.

KING, R. and MAI, N. 2002 Of myths and mirrors: interpretations of Albanian migration. Studi Emigrazione, vol. 39, no.145, pp. 161-199.

KING, R. and MAI, N. 2004 Albanian immigrants in Lecce and Modena: narratives of rejection, survival and integration. Population, Space and Place, vol. 10, no. 6, pp. 455-477. 
LABRIANIDIS, L. and LYBERAKI, A. 2004 Back and forth and in-between: Albanian return-migrants from Greece and Italy. Journal of International Migration and Integration, vol. 5, no. 1, pp. 77-106.

LAZARIDIS, G. 1996 Immigration into Greece: a critical evaluation of Greek policy. New Community, vol. 22, no. 2, pp. 335-348.

MAI, N. 2002 Between Losing and Finding Oneself. The Role of Italian Television in the Albanian Migration to Italy. Brighton: University of Sussex. DPhil thesis in Media and Cultural Studies.

MAI, N. 2003 The cultural construction of Italy in Albania and vice versa: migration dynamics, strategies of resistance and politics of mutual self-definition across colonialism and post-colonialism. Modern Italy, vol. 8, no. 1, pp. 77-93.

MAI, N. 2005 The Albanian diaspora-in-the-making: media, migration and social exclusion, Journal of Ethnic and Migration Studies, vol. 31, no. 3, pp. 543561.

MELCHIONDA, U. 2003 Gli Albanesi in Italia: Integrazione Lavorativa e Sociale, Rome: Franco Angeli.

PALOMBA, R. and RIGHI, A. 1992 Quel giorno che gli Albanesi invasero l'Italia ... Gli atteggiamenti dell'opinione pubblica e della stampa italiana sulla questione delle migrazioni dall'Albania. Working Paper 08/92. Rome: Istituto di Ricerche sulla Popolazione.

PERLMUTTER, T. 1998 The politics of proximity: the Italian response to the Albanian crisis. International Migration Review, vol. 32, no. 1, pp. 203-222.

PERRONE, L. (Ed.) 1998 Né Qui Né Altrove: I Figli degli Immigrati nella Scuola Salentina, Rome: Sensibili alle Foglie.

PORTES, A. and RUMBAUT, R. 1996 Immigrant America: A Portrait, Berkeley: University of California Press.

PORTES, A. and ZHOU, M. 1993 The new second generation: segmented assimilation and its variants among post-1965 immigrant youth. Annals of the American Academy of Political and Social Science, vol. 530, pp. 74-98.

ROMANIA, V. 2004 Fare Passare per Italiani: Strategie di Mimetismo Sociale, Rome: Carocci.

SALIH, R. 2003 Gender in Transnationalism: Home, Longing and Belonging Among Moroccan Migrant Women, London: Routledge. 
SAMPSON, S. 1998 Exporting democracy, preventing Mafia: rebirth of Eastern Europe in the era of post-post-communism. IN KARLSSON, K., PETERSSON, B. and TÖRNQUIST-PLEWA, B. (Eds) Collective Identities in an Era of Transformations: Analyzing Developments in East and Central Europe and the Former Soviet Union. Lund: Lund University Press, pp. 151186.

SCHMIDT DI FRIEDBERG, O. 1994 Islam, Solidarietà e Lavoro: I Muridi Senegalesi in Italia, Turin: Fondazione Giovanni Agnelli.

SCHUSTER, L. 2005 The continuing mobility of migrants in Italy: shifting between places and statuses. Journal of Ethnic and Migration Studies, vol. 31, no. 4, pp. 757-774.

SPONZA, L. 1988 Italian Immigrants in Nineteenth-Century Britain: Realities and Images, Leicester: Leicester University Press.

STELLA, G. A. 2002 L'Orda: Quando gli Albanesi Eravamo Noi, Milan: Rizzoli.

TER WAL, J. 2002 Italy. IN TER WAL, J. (Ed.) Racism and Cultural Diversity in the Mass Media. Vienna, European Monitoring Centre on Racism and Xenophobia, pp. 239-272.

VEHBIU, A. and DEVOLE, R. 1996 La Scoperta dell'Albania. Gli Albanesi secondo i Mass-Media, Milan: Paoline.

VERMEULEN, H. and PENNINX, R. 2000 Immigrant Integration: The Dutch Case, Amsterdam: Het Spinhuis.

ZINCONE, G. 2006 The making of policies: immigration and immigrants to Italy. Journal of Ethnic and Migration Studies, vol. 32, no. 3, pp. 347-375.

ZINN, D. L. 1996 Adriatic brethren or black sheep? Migration in Italy and the Albanian crisis, 1991. European Urban and Regional Studies, vol. 3, no. 3, pp. 241-249.

ZINN, D. L. 2005 The second generation of Albanians in Matera: the Italian experience and prospects for future ties to the homeland. Journal of Southern Europe and the Balkans, vol. 7, no. 2, pp. 259-277.

\footnotetext{
${ }^{1}$ We must remind ourselves, at this point, of the timing of Gordon's conclusion, before the arrival of so-called 'new immigrants', largely from non-European countries, post-1965.

${ }^{2}$ Greece is also a neighbouring EU country but has always been seen as a less desirable destination for migration because of the historical antagonism between the two countries. For those living in Tirana and in the western, coastal regions, Italy was, in fact, closer than Greece which lies far to the south over
} 
high mountain ranges breached only by two roads. Furthermore, Greek wages are lower than those attainable in Italy.

${ }^{3}$ Cole (1997) and Daly (2001) find similar results for Tunisians and Moroccans in Sicily and northern Italy.

${ }^{4}$ Other historical factors are at play here. Most migrants grew up under communist atheism which weakened their religious identity. Meanwhile Romanians, whose numbers have increased sharply in the last couple of years, have taken their place alongside Albanians as the most negatively perceived group in Italy.

${ }^{5}$ Indeed Stella makes the specific link between the Italian emigration experience then and the Albanian experience in Italy now - the subtitle to his book being 'When we were the Albanians'.

RUSSELL KING is Professor of Geography at the University of Sussex.

ADDRESS: Department of Geography, University of Sussex,

Brighton, BN1 9SJ, UK. Email: R.King@ sussex.ac.uk

NICOLA MAI is Senior Research Fellow in the Institute for the Study of European Transformations, London Metropolitan University. ADDRESS: London Metropolitan University, 166-220 Holloway Road, London, N7 8DB, UK. Email: N.Mai@londonmet.ac.uk 
Table 1 Albanians in Italy with permits-to-stay, 1991-2005

\begin{tabular}{rrrrr}
\hline Year & No. & Rank & \% of total & \multicolumn{1}{c}{$\begin{array}{c}\text { Total } \\
\text { immigrants }\end{array}$} \\
\hline 1991 & 26,381 & 9 & 3.1 & 859,571 \\
1995 & 34,706 & 7 & 3.5 & 991,419 \\
2000 & 142,066 & 2 & 10.2 & $1,388,153$ \\
2005 & 255,704 & 2 & 11.3 & $2,271,680$ \\
\hline
\end{tabular}

Note: Data are for 31 December of each year

Source: King (2003, p. 290); Caritas/Migrantes (2006, p. 116).

Table 2 Demographic indicators of Albanians and all immigrants in Italy, 1992 and 2000 (\% data)

\begin{tabular}{lrrrc}
\hline & \multicolumn{2}{c}{ Albanians } & \multicolumn{2}{c}{ All immigrants } \\
& 1992 & 2000 & 1992 & 2000 \\
\hline \% males married & 22.4 & 44.8 & 36.9 & 45.3 \\
\% females married & 60.0 & 72.9 & 42.1 & 54.8 \\
\% immigrants with children & 7.1 & 18.7 & 7.2 & 13.3 \\
\hline
\end{tabular}

Note: 'All immigrants' means immigrants from 'countries of strong migratory pressure', which includes developing countries and countries of Central and Eastern Europe, but not other European or developed countries.

Source: Bonifazi and Sabatino (2003, p. 979).

Table 3 Albanian pupils in the Italian school system, 1995-96 - 2003-04 (\% refers to share of all immigrant-origin pupils)

\begin{tabular}{lrrrr}
\hline school level & \multicolumn{2}{c}{$1995-96$} & \multicolumn{2}{c}{$2003-04$} \\
& no. & $\%$ & \multicolumn{1}{c}{ no. } & $\%$ \\
\hline nursery & 802 & 7.7 & 9,735 & 17.7 \\
primary & 2,235 & 9.3 & 20,930 & 18.2 \\
middle & 686 & 7.2 & 11,538 & 17.1 \\
secondary & 418 & 6.5 & 7,762 & 17.3 \\
total & 4,141 & 8.2 & 49,965 & 17.7 \\
\hline
\end{tabular}

Source: Bonifazi and Sabatino (2003, p. 980); Caritas/Migrantes (2004, p.169). 